\title{
A synoptic overview of durum wheat production in the Mediterranean region and processing following the European Union requirements
}

\author{
Fernando Cebola Lidon ${ }^{1 *}$, Ana Sofia Almeida ${ }^{2}$, Ana Lúcia Leitão ${ }^{1}$, Maria Manuela Silva ${ }^{3}$, Nuno Pinheiro², \\ Benvindo Maçãs ${ }^{2}$ and Rita Costa ${ }^{2}$ \\ ${ }^{1}$ Departamento de Ciências e Tecnologia da Biomassa, Faculdade de Ciências e Tecnologia, Universidade Nova \\ de Lisboa, 2825-114 Caparica, Portugal \\ ${ }^{2}$ Instituto Nacional de Investigação Agrária e Veterinária, Estrada de Gil Vaz, Apartado 6, 7350-591 Elvas, \\ Portugal \\ ${ }^{3}$ ESE Almeida Garrett, Grupo Universidade Lusófona, COFAC, Palácio de Santa Helena, Largo do Sequeiro \\ $n^{\circ}$ 7, Lisboa, Portugal
}

\begin{abstract}
Cereals are a group of cultivated plants belonging to the grass family that produces grains rich in starch with specific dough properties. These grains are easily harvested, due to the structure and, if under appropriate storage, the mature seeds preserve its qualities and nutritional value for a long time. The gradual shift to a steady-production based agriculture has been the main driving force behind the domestication of wheat, namely durum wheat. The world durum wheat steady-production, which prevails in the Mediterranean region, is mostly used in the production of pasta, yet the quality definition requires the control of fungal phytopathogens, industrial unit operations and additives applications. This paper reviews some aspects of durum wheat production and industrial processing, further considering phytopathogenic infections and the application of food additives.
\end{abstract}

Key words: Durum wheat production, Food additives, Industrial processing of pasta, Phytopathogens

\section{Origin, domestication and evolution of wheat}

The earliest signs of crop domestication appeared 10,000-12,000 years ago in the Fertile Crescent of the Near East, in the Central America, and in the southern of China. In the Fertile Crescent of the Near East, near of Tigris and Euphrates rivers, wheat domestication was founded on crop reliability, yield and suitability for storage (LevYadun et al., 2000). Eventually, man collected and possibly cultivated wild forms of wheat, selecting for nonshattering, free-threshing, non-brittle rachis and hull-less spike characteristics and for higher yield. Also, in all cereals, the easiness of harvest,

Received 07 May 2013; Revised 12 May 2014; Accepted 18 May 2014; Published Online 15 June 2014

*Corresponding Author

Fernando Cebola Lidon

Departamento de Ciências e Tecnologia da Biomassa, Faculdade de Ciências e Tecnologia, Universidade Nova de Lisboa, 2825-114 Caparica, Portugal

Email: fjl@fct.unl.pt yield and suitability for short and long-term storage have been critical for domestication.

The evolution and domestication of various forms of cultivated wheat (diploid - Triticum monococcum, tetraploid - Triticum turgidum and hexaploid-Triticum aestivum) within the entire Triticeae tribe included early widespread intragenome and intergenome hybridization, followed by introgression, gene flow, gene fixation and rapid diversification within and among the ancestral diploid and polyploid species (Kellogg et al., 1996).

Wheat cultivation spread in all directions, but the Mediterranean basin played an important role in its differentiation, in particular of durum wheat (Núñez, 2003). In the Iberian Peninsula, the cultivation of wheat was found 4,000 years ago (López Bellido, 1991).

Modern wheat cultivars belong primarily to two polyploid species, namely hexaploid bread wheat Triticum aestivum L. ( $2 \mathrm{n}=6 \mathrm{x}=42$ chromosomes) and tetraploid hard or durum-type wheat - Triticum turgidum L. (Thell.) ( $2 \mathrm{n}=4 \mathrm{x}=28$ chromosomes). 


\section{Durum wheat production and consumption in the world}

Durum wheat production reaches around 30 million tons in about 16 million hectares. Durum wheat productions areas are concentrated in the Middle East, North Africa, the former USSR, the North American Great Plains, India and Mediterranean Europe. The Mediterranean region produces about $60 \%$ of world durum wheat production (Morancho, 2000), being the European Union (Italy, Spain, France and Greece) the leading global producer. Despite these numbers, the production of durum wheat represents only $8 \%$ of world production of wheat (Manzano, 2007).

In general durum wheat is colder sensitive than bread wheat, but is better adapted to high temperatures and to semiarid climates, being insolation important to this crop. Such tolerance to higher temperatures seems to be related to a higher tolerance of the photosynthetic metabolism (Dias et al., 2011), probably related to a higher thermal stability of cellular membranes (Dias et al., 2010). Favourable zones for durum wheat maturation require an average of more than 250 hours of sun during the harvest preceding month. Eventually, these conditions prompt the traditional implementation of this crop in the semi-arid zones of the Mediterranean basin (Royo, 1998).

In spite of its relatively low area of production, durum wheat is an economically important crop due to its unique characteristics and end products. It is generally considered the hardiest of all wheat. Durum kernels are usually large, golden amber, and translucent. These characteristics, as well as its protein content and gluten strength, make it suitable for manufacturing diverse food products, namely pasta that is the most common durum wheat end product consumed in Europe, North America and in the former USSR countries. Indeed, Italy tops the world rankings from consumption of dry pasta per capita/year with a value of $28 \mathrm{~kg} /$ inhabitant/year, followed by USA, Chile, Greece, Venezuela, Tunisia, Switzerland, Peru and, finally, France, Russia and Argentina with an average consumption of $9 \mathrm{~kg}$ per inhabitant/year (Roncallo et al., 2009). Additionally, couscous, are also made from durum wheat semolina, being largely consumed in North Africa (Algeria, Morocco and Tunisia) and Middle East, whereas flat bread made from durum wheat and bulgur are part of the main diet in Jordan, Lebanon, and Syria (Nachit et al., 1992; Quaglia, 1988; Palumbo et al., 2000).

\subsection{Climate, Agronomy and Quality}

By its extensive ability to adaptation, wheat is cultivated in a wide variety of climates. The latitude having favourable cultivation area extends between $30^{\circ}$ and $60^{\circ}$ north and $25^{\circ}$ and $40^{\circ}$ south, mostly in regions whose precipitation ranges between 300 and $1000 \mathrm{~mm}$ annually (González and Rojo, 2005). As wheat was originated in dry climate regions, it became well adapted to the steppes, where it is intensely sown. It can also be produced in areas of relatively cool and humid weather during the growing season, followed by a hot and dry period during grain filling.

In the Mediterranean climate, which prevails in the south/southwest of Europe, North Africa, California, Chile, South Africa and South Australia, the summer is very long, hot and dry and the precipitation is concentrated in autumn and winter. Winter is also often short and mild (Maçãs, 1996). The regions with this type of climate represent 10$15 \%$ of the total production of wheat globally (Loss and Siddique, 1994).

The water deficit is one of the main factors limiting durum wheat yield in the Mediterranean region (Bennet et al., 1998). Temperature starts to rise in spring, often sharply which concurs with the cereal water demand. However, rainfall in this season is often relatively low and very irregular, which can also cause water deficit problems, together with high temperature exposure. This stage normally coincides with the emergence, flowering and grain filling, triggering reduction in the number of spikes by plant and in the number of grain per spike and frequently also grain weight reduction (López Bellido, 2009; Maçãs et al., 1999, 2000). Performance is determined by the distribution of total rainfall during crop development (Slafer, 2003; Cossani et al., 2009). Thus, the unpredictability of the Mediterranean climate causes fluctuations in wheat yield and quality, but offers the opportunity for obtaining high-quality durum wheat in terms of the most important parameters required by industry (Table 1 ).

Table 1. Range values for high quality durum wheat parameters.

\begin{tabular}{ll}
\hline Quality parameters & Range values \\
\hline Protein Content (\%) & $>13$ \\
Yellow Pigment Content (ppm) & $>7$ \\
Ash Content (\%) & $<1,8$ \\
Vitreousity (\%) & $>75$ \\
Wet Gluten Content (\%) & $>40$ \\
Test Weight (kg/hl) & $>78$ \\
Hagberg Index (s) & $>250$ \\
SDS Sedimentation Test (mm) & $>50$ \\
Moisture Content $(\%)$ & $<12$ \\
\hline
\end{tabular}


The performance of many quality characteristics depends greatly on environmental conditions, which result in differential expression of grain quality from site to site. In fact, grain protein content, perhaps the most important quality feature for wheat, is known to be influenced by climatic parameters, cultivar, nitrogen fertilizer rate, time of nitrogen application, residual soil nitrogen and available moisture during grain filling (Campbell et al., 1981; Rao et al., 1993; Uhlen et al., 1998; Rharrabti et al., 2001). Vitreousness is mainly affected by nitrogen and water availability, and humid environments reduce the percentage of vitreous grains and increase the incidence of black point (Robinson et al., 1979). Environmental conditions can also influence ash content, which increases under high-transpiration environments (Araus et al., 1998). Thousand-kernel weight and test weight are greatly determined by climatic parameters, particularly high temperature during the grain filling. Gluten strength, can also be reduced in dry and hot environments (Blumenthal et al., 1991; Graybosh et al., 1995; Rharrabti et al., 2003).

\subsection{Phytopathogenic fungal infections}

Wheat infections caused by phytopathogenic fungal strains able to produce toxic metabolites, such as trichothecenes, zearalenone, aflatoxins, fumonisins and ochratoxin A, sterigmatocystin, T-2 toxin have relevant implications. These toxic compounds are low molecular weight secondary fungal metabolites known as mycotoxins (Prandini et al., 2009). The presence of mycotoxins, exerts a severe adverse effect on human and animal health due to their recognized toxic properties, which depend on the mycotoxin and its dose. It is well known the biological effects in animals, such as liver and kidney toxicity, effects on the immunological and central nervous system among others (Whitlow and Hagler, 2005). On the other hand, the contamination of wheat with mycotoxins has serious economic consequence. The grain quality is compromised not only by deterioration with selective loss of albumin and gluten proteins, but also with important losses in grain yield (Muller et al., 2010). Due to the global importance of wheat in the human diet or animal feed its susceptibility to be contaminated by fungi or/and by their natural toxins is a concerning fact (Table 2). HACCP approach is an important tool in order to quantify hazards and identify critical control points for controlling mycotoxin production and its entry into food chain and also to know the threshold limits for growth (Hope and Magan, 2003).
The capacity of a mycotoxin-producing strain to contaminate the cereal depends on several factors such as genetic, composition of grain, environmental and agricultural management. The different crop management practices, such as crop rotation, tillage and cultivar were pointed out as important abiotic drivers (Muller et al., 2010). For instance, Muthomi et al. (2008) reported that the management strategies for Fusarium head blight include crop rotation, seed treatment, planting different cultivars, irrigation and weed control, proper land preparation, timely harvesting, appropriate use of fertilizers and fungicide application (Muthomi et al., 2008).

It is known that the initial infection of a floret follow the spread to the spikelets of the same head. However, there is controversy about the mechanism of nutrition use by these pathogenic fungi. A microscopic study conducted by Brown et al. (2010) reported that Fusarium graminearum PH-1 hyphae colonized susceptible wheat ears and spread from spikelet to spikelet, adapting their hyphae to the available intracellular space between host cells, resulting the loss of their entire cellular contents just prior to intracellular colonization. According to these authors the advancing cortex infections progress resulted in the collapse of the non-lignified cell types, the pathogen draw from predominately vertical to lateral growth and accumulated below the surface of the rachis. At this stage the lignified host cell walls became profoundly degraded and hyphae ruptured the epidermis and produced an aerial mycelium (Brown et al., 2010).

There are several fungal strains able to produce natural toxins that are extremely susceptible to environmental factors, such as temperature, relative humidity, insect attack, pests damage, fertilization balance and stress condition (Schmidt-Heydt et al., 2009). The presence of these secondary metabolites has been reported at different stage of the food chain, such as pre-harvest, processing, transportation and finally in the storage, indicating that fungus colonization may occur before or after harvest, depending upon environmental or storage conditions. In the case of ochratoxins, the production and occurrence of this mycotoxin in the cereal grains is deeply dependent on the condition of the grain at harvest, how carefully the grain is dried and the quality of the storage facilities (Duarte et al., 2010). Since chemical composition of seeds involves their moisture content, seeds with high oil content have less moisture than seeds with high protein or starch content. For example, moisture content below $20 \%$ prevents ochratoxin A 
production (Scudamore et al., 1999). Besides that, it has been described that high content of ochratoxin amino acid precursors, such as glutamic acid could be a cofactor for the mycotoxin production (Gonzalez-Osnaya et al., 2007).

Nowadays, it is known more than 300 natural toxins isolated and characterized, aflotoxins and ochratoxins are the most important among them. They represent an important group based on their toxicity and occurrence. Indeed, ochratoxin A represent the most widespread mycotoxin in the wheat (Duarte et al., 2010). The EU regulation established for ochratoxin A values of $5 \mu \mathrm{g} / \mathrm{kg}$ for raw cereal and $3 \mu \mathrm{g} / \mathrm{kg}$ for all products derivated from cereals (CEC, 2006). In the case of aflatoxin B1 and the total of aflatoxins a limit set of $2 \mu \mathrm{g} / \mathrm{kg}$ and $4 \mu \mathrm{g} / \mathrm{kg}$ was established, respectively (UE, 2010). Recently it was found $3.0 \mu \mathrm{g} / \mathrm{kg}$ of ochratoxin in the wheat (Ghali et al., 2008). Moreover, it was reported in Kenya wheat products the presence of more than one of the four mycotoxins analyzed (Muthomi et al., 2008). The co-occurrence of different mycotoxins in the grain can affect both the level of mycotoxin production as well as the toxicology of the contaminated grain resulting in synergetic and additive effects (Muthomi et al., 2008).

According to International Agency of Research of Cancer (IARC, 1993), aflatoxins were considered as a possible human carcinogen. Previous studies showed that these mycotoxins have immunosuppressive, teratogenic and hepatotoxic properties. On the other hand, teratogenic, genotoxic, embryotoxic, immunosuppressive, carcinogenic, neurotoxic and nephrotoxic effects have been described as a consequence of ochratoxin A activity (JECFA, 2001).

Mycotoxins are produced by several fungal strains of Fusarium spp., Aspergillus spp. and Penicillium spp. (Schmidt-Heydt et al., 2008). These three fungal species are filamentous ascomycetes and are the most casual agents of wheat disease. Depending on the fungal species the mycotoxins produced have different toxigenic profiles. It has been reported that each strain shows different behaviors in what concerns to geographical occurrence and ecological niches. For example, in tropical regions Aspergillus ochraceus is the main responsible for ochratoxin A production, meanwhile in temperate to cool climatic regions Penicillium verrucosum that grows optimally below $30^{\circ} \mathrm{C}$ and with water activity (aw) values of 0.80 was described as the principal agent of wheat disease (Zinedine et al., 2006). Indeed, there are several Aspergillus species known to be able to produce ochratoxin A, some of them appear in the countries with warm temperatures, while others are found in tropical and sub-tropical ones, showing a clear relation between mycotoxin occurrence and climatic conditions, particularly in what concerns to moisture and temperature (Duarte et al., 2010). These two factors are critical growth parameters. The strains Aspergillus ochraceus, A. westerdijkiae and $A$. steynii have an optimal temperature of $24-31^{\circ} \mathrm{C}$ and aw values of $0.95-0.99$. Meanwhile, A. niger grows optimally at temperatures of $35-37^{\circ} \mathrm{C}$ (range from 6 to $47^{\circ} \mathrm{C}$ ) and at low values of aw (0.77) (Duarte et al., 2010). Aspergillus species also are known as the most important fungal species able to produce aflatoxins, particularly Aspergillus flavus and Aspergillus parasiticus. At temperatures of 25,30 and $35^{\circ} \mathrm{C}$ biosynthesis pattern of aflatoxin followed the growth rate and was high at 0.99 aw and low at 0.90 aw. Highest amounts of aflatoxin were produced between 25 and $30^{\circ} \mathrm{C}$, but also under temperatures of $20^{\circ} \mathrm{C}$. However, very low amounts of aflatoxin were produced at more than $37{ }^{\circ} \mathrm{C}$ and aw values of 0.90 (Schmidt-Heydt et al., 2008).

One of the most important diseases produced by Fusarium spp. that recently re-emerged is fusarium head blight (FHB) (Muthomi et al., 2008). Fusarium spp. is known to produce zearalenone and trichothecenes, such as deoxynivalenol and nivalenol. Fusarium culmorum and $F$. graminearum grows over a wider aw range $(0.90$ 0.99 ) at 15 and $25^{\circ} \mathrm{C}$, while a water activity of 0.95 0.99 was required for deoxynivalenol and nivalenol production at the same range of temperature. The highest concentration of deoxynivalenol and nivalenol levels were produced at $25^{\circ} \mathrm{C}$ and with aw values of 0.995 and 0.981 , respectively, after 40 days of incubation (Hope and Magan, 2003). It is well documented that weather conditions influence different parts of the infection cycle, for example from prolonged period of warm humid conditions results in infections of cereal by Fusarium spp.

The biosynthesis of mycotoxins is highly regulated by external factors at the level of transcription. It has been reported that general growth parameters, such as substrate, water activity, temperature and $\mathrm{pH}$, affect mycotoxins production (Reverberi et al., 2010). Schmidt-Heydt et al. (2008) described the influence of these abiotic factors by real-time PCR and microarray analysis on the expression of mycotoxin biosynthetic genes from Aspergillus parasiticus, Penicillium verrucosum and Fusarium culmorum, and concluded that aw, $\mathrm{pH}$ and temperature in a 
similarly way activated the genes for mycotoxin biosynthesis. Moreover, the results indicate that the expression of mycotoxin biosynthetic genes was observed close to optimum growth conditions and at moderate stress conditions (Schmidt-Heydt et al., 2008). More recently, the same team showed that certain combinations of aw and temperature, especially combinations which imposed stress on the fungus resulted in a significant reduction of the growth rate. At these conditions induction of the whole aflatoxin biosynthesis gene cluster occurred, however the level of produced aflatoxin B1 was low (Schmidt-Heydt et al., 2009).

Besides these abiotic factors it has been shown that certain conditions or the presence of several molecules can be a source of stress and consequently induce mycotoxin production. Jayashree and Subramanyam (2000) reported that higher levels of oxygen during trophophase trigger the aflatoxin production by Aspergillus parasiticus. According to the same authors, the results suggested that the biosynthesis of aflatoxin could be a consequence of an increasing of oxidative stress leading to enhanced lipid peroxidation and free radical generation. Furthermore, a study conducted by Narasaiah et al. (2006) support the idea that the formation of aflatoxin and its precursors, such as norsolorinic acid, versicolorin and O-methyl sterigmatocystin, by A. parasiticus may occur as a compensatory response to reactive oxygen species accumulation (Narasaiah et al., 2006). The effect of light on ochratoxin A production of Aspergillus carbonarius, A. niger, A. steynii and on Penicillium nordicum and $P$. verrucosum was dependent on the fungus and growth medium but generally the light had negative effect on ochratoxin A biosynthesis (SchmidtHeydt et al., 2011). Schmidt-Heydt et al. (2007) described the positive effect of suboptimal concentrations of preservatives, such as potassium sorbate and calcium propionate in biosynthesis of ochratoxin A by Penicillium verrucosum. The ochratoxin A production was stimulated by 150 and $300 \mathrm{mg} / \mathrm{L}$ of both preservatives, particularly at values of aw 0.95 and 0.93 . Additionally, these authors showed that if water activity as a single factor was modified, a typical ochratoxin A production and otapksPV expression profile occurred, indicating that ochratoxin A synthesis is activated under optimal growth conditions and under weak stress conditions (Schmidt-Heydt et al., 2007).

As it was previously described and is generally accepted, stress is mentioned as a factor that switchs on mycotoxin biosynthesis (Schmidt-Heydt et al., 2008). Meanwhile, mycotoxin could be detected after fungus died as they are usually stable for a long period of time (Ayalew et al., 2006).

The changes in weather conditions and the modifications of the biogeographical scenarios of crop cultivation could trigger the adoption of new GAPs targeted to face fungal contaminations and mycotoxin synthesis (Miraglia et al., 2009). Furthermore, the direct relation of the infection to environmental factors makes possible to focus the future research in the following points (Miraglia et al., 2009): harmonization of procedures for the surveillance and monitoring of mycotoxins across Europe; evaluating the feasibility of a database on the geographical distribution of mycotoxins; development of models for the prediction of the novel biogeographical agricultural scenarios of cultivated plants and of the related moulds/mycotoxins; assessment of the influence of multiple environmental factors on mycotoxin contamination.

It seems of consensus that the production of mycotoxins can be regarded as an adaptation to imposed abiotic and other stress factors by several fungus strains. The pathway of mycotoxin biosynthesis is activated under optimal growth conditions and under weak stress conditions. However, if two or more factors are at suboptimal values the toxin gene expression ceases. Whether the activation of mycotoxin is the cause or the consequence of a stress reaction is still yet unknown. Taking into account all the considerations of this section the best control strategies in order to avoid wheat contamination by mycotoxins is to ensure the complete inhibition of fungal growth strains. 
Table 2. Occurrence of mycotoxins and contamination ranges.

\begin{tabular}{|c|c|c|c|c|}
\hline Mycotoxin & Country (year) & $\begin{array}{l}\text { Positive } \\
\text { samples (\%) }\end{array}$ & $\begin{array}{l}\text { Contamination range } \\
(\mu \mathrm{g} / \mathrm{kg})\end{array}$ & Reference \\
\hline \multirow{3}{*}{ Aflatoxin B1 } & Ethiopia (1999) & 4.2 & n.d. -12.3 & (Ayalew et al., 2006) \\
\hline & & & n.d.- 1388.0 & (Qutet et al., 1983) \\
\hline & Kenya (2004) & 41.0 & $0-7.0$ & (Muthomi et al., 2008) \\
\hline \multirow{6}{*}{ Ochratoxin A } & Poland (1998) & 48.6 & $0.60-1024$ & (Czerwiecki et al., 2002) \\
\hline & Ethiopia (1999) & 23.4 & $4.2-66.0$ & (Ayalew et al., 2006) \\
\hline & Bulgarian & & $0.5-39.0$ & (D'Mello, 2004) \\
\hline & Italy (1999-2000) & 8.6 & n.d. - 1.4 & (Palermo et al., 2002) \\
\hline & Morocco & 40 & $0.04-0.80$ & (Zinedine et al., 2006) \\
\hline & Tunisia & 38 & n.d. - 940 & (Zaied et al., 2009) \\
\hline \multirow{4}{*}{ Deoxynivalenol } & Ethiopia (1999) & 16.7 & $50-110$ & (Ayalew et al., 2006) \\
\hline & Kenya (2004) & 75.0 & $105-303$ & (Muthomi et al., 2008) \\
\hline & Germany (2006) & n.d. & $20-2960$ & (Muller et al., 2010) \\
\hline & Germany (2007) & n.d. & n.d. -20320 & (Muller et al., 2010) \\
\hline \multirow{2}{*}{ Nivalenol } & Ethiopia (1999) & 4.3 & 40 (1 sample) & (Ayalew et al., 2006) \\
\hline & Japan & & 4400 & (Yoshizawa, 1997) \\
\hline \multirow{4}{*}{ Zearalenone } & Ethiopia (1999) & 0 & 0 & (Ayalew et al., 2006) \\
\hline & Kenya (2004) & 60 & $1.6-35$ & (Muthomi et al., 2008) \\
\hline & Germany (2006) & n.d. & $<2.0-6.0$ & (Muller et al., 2010) \\
\hline & Germany (2007) & 15.6 & n.d.- 2543 & (Muller et al., 2010) \\
\hline
\end{tabular}

\section{Industrial durum wheat processing \\ 3.1. Production of pasta}

A quality pasta product requires high quality raw material (Toussaint-Samat, 1992). Durum wheat, which preserves for a long time its qualities and nutritional value (López Bellido, 2009), being ideally suited for pasta, is weighed, sampled and analyzed, passed through a preliminary cleaner and magnet, then stored according to grade. Meticulous cleaning is also required for durum wheat. Cleaners remove weed seeds, dirt and other extraneous material through machines which separate by size, specific gravity, and shape. Frictional cleaning equipment (scourers) scours the surface of the kernel, removing the outermost layers of the bran. Therefore the grains are tempered. During tempering, water is added to toughen the outer bran coats for easier separation from the endosperm. Tempering also mellows the endosperm for grinding. Durum wheat is usually tempered for a relatively short time, yet some technology in pasta manufacturing also enables finer semolina to be used for longer tempering periods.

In the industrial production of pasta (Lidon and Silvestre, 2007) milling is essentially a grinding and separating development. Grinding is done on break rolls, sizing rolls and reduction rolls. Separation is carried out using sifters and purifiers machines. A durum mill has an extended break system in which grinding is relatively gradual. The endosperm is released in coarse granular form rather than as flour. The grading, purifying and sizing systems are more extensive in a durum mill, but the reduction system is very small compared to that of a flour mill.

The main product of durum milling, the so called semolina, is coarser than the flour produced in common wheat milling (Toussaint-Samat, 1992). Desirable characteristics for semolina include good colour, minimum dark or bran specks and uniform granulation. Small amounts of fine semolina and flour are produced. These are often combined with normal semolina to obtain blended material that can be used for a wide range of long and short pasta types. The semolina is stored in silos that can hold up to $68,100 \mathrm{~kg}$. To manufacture the pasta, pipes move the flour to a mixing machine equipped with rotating blades. Warm water is also piped into the mixing machine.

The mixing can be prepared using an automatic continuous mixer or with semi-automatic batch mixers. In the former case the ingredients are blended and dosed automatically in a centrifuge according to pre-programmed recipes. In semiautomatic batch mixing ingredients are dosed manually, with the mixing being prepared in a secondary hopper and transferred to the forming machine only when the batch is ready. The mixture is kneaded to a paste consistency.

To develop flavored and colored pasta, eggs can be added to the mixture if the product is an egg noodle. If pasta is to be a flavored variety, 
vegetable juices can be added. A tomato or beet mixture is added for red pasta, spinach for green pasta, carrots for orange pasta. Herbs and spices can also be folded in for additional flavoring. Food additives can be added, to fresh pasta, in order to obtain quality products with the requirements of the consumers.

For product forming, the dough can further be shaped into non-filled pasta through extrusion, shaping on a belt and lamination (Lidon and Silvestre, 2007). Extrusion allows producing the wider range of products in the easier way. The dough is compressed at high pressure and forced through the tiny holes of a die. A die is a basic component of a press: the dough, formed in the kneading tank and then driven by the extrusion screw towards the head of the press, is forced through the die. A die is composed of a main support, normally made of bronze. This support is drilled with special techniques and each hole is made to house a drawing insert. The shape and type of insert determines the final shape of the pasta. The dough is pressed through the insert, which provides the basic structure of the pasta (tube, hollow, spiral). Behind the die there is often an additional structure that bends, folds or cuts the pasta to form the final shape. The classic material for the insert is bronze, which is still entirely used to make traditional dies. Dies made entirely of bronze have the feature of giving the surface of the pasta a minutely jagged and porous appearance, with highlights making it look white: this is a direct consequence of the nature of the material used for the die since the surface of bronze is never perfectly smooth. The extruded pasta is then cut to the desired length. This process is used to produce the better known shapes of non-filled pasta, like spaghetti, maccheroni, fusilli, penne, and more complicate shapes like radiators or wheels.

Shaping on a belt allows only the production of special shapes, traditionally twisted or dragged by hand (Giese, 1992). The dough is twisted and dragged on a conveyor belt to simulate the work of the hand and obtain the desired shape, like trofie, cavatelli, olive leaves, etc. Even though all pasta is produced with the same raw materials, each shape, in a certain sense, has its own personality: as regards, for instance, the type of sauce that best goes with it; or the way of using it, with meat or vegetable stock, or drained and served with sauces of every kind. Pasta shapes stimulate culinary creativity because they are themselves the outcome of a creative process. The countless shapes of pasta are the basis for thousands of possible recipes, each one different and characteristic.

In the lamination process the mixture is pressed into sheets by large cylinders. A vacuum mixermachine further flattens the dough while pressing air bubbles and excess water from the dough to reach the optimum water content of $12 \%$. Laminated pasta or pasta shaped on belts sometimes is sold fresh. In this case the product is pasteurized (overheated for a short time to reduce bacteria charge) to increase its shelf-life. Pasta is carried by conveyor belts through a pasteurizing tunnel and then through a cooling tunnel. All the process can be automatic and continuous without contacts with the operator.

Depending on the pasta shape to be produced, the dough is either cut or pushed through dies (Lidon and Silvestre, 2007). Ribbon and stringstyle pasta such as fettuccine, linguine, spaghetti, and capellini (angel hair pasta) are cut by rotating blades. Making pasta in a tube or shell shape such as rigatoni, ziti, elbow pasta, macaroni, and fusilli, the dough is fed into an extruder which then pushes it through metal dies. The size and shape of the holes in the die determine the type of pasta. Making pasta shaped like vermicelli and capellini, the pasta dough is pushed through holes between $0.8-0.5 \mathrm{~mm}$ in diameter. The cutting machine then cuts the pasta into lengths of $25 \mathrm{~cm}$ and twists it into curls or left straight. Tortellini (filled pasta) is made on a separate machine. The machine cuts small circles from a roll of dough. A bucket of ricotta cheese or filling mixture drops a pre-measured amount of filling onto the circle of dough. The dough is then folded over and the two ends are joined to form a circle. This is referred to as a tuck and fold machine. To make ravioli (filled pasta squares), pre-measured quantities of cheese or filling are dropped by a machine at pre-measured intervals on a sheet of pasta. Another sheet of pasta is placed over this sheet as it moves along a conveyor belt. The two layers then pass under a cutting machine that perforates the pasta into pre-measured squares.

Drying is the thermal process more widely used to preserve non filled pasta (Lidon and Silvestre, 2007). Humidity rate of the product is significantly reduced in suitable drying rooms according to proper temperature and humidity cycles. Drying cycles are critical to obtain a good result. Drying cycle can be completely automatic on conveyor belts for high productions or semi-automatic on trays and trolleys for lower productions. The pasta is placed in a drying tank in which temperature, moisture and drying time are strictly controlled. 
The drying period differs for the various types of pasta. The drying time in making pasta can range from three hours for elbow macaroni and egg noodles to as much as 12 hours for spaghetti. The drying time is critical because if the pasta is dried too quickly it will break and if it is dried too slowly, the chance for spoilage increases. The oxygen level in the tank is also controlled, and lab technicians test frequently for salmonella and other bacteria. Careful handling of the pasta during the drying period is also crucial. Spaghetti is the most fragile of the noodles and is therefore hung high above the floor.

For packing, fresh pasta is folded in premeasured amounts into clear plastic containers (Lidon and Silvestre, 2007). As the containers move along a conveyor belt, a plastic sheet covers each container and is sealed with a hot press. At the same time, a small tube sucks the air from the container and replaces it with a mixture of carbon dioxide and nitrogen to prolong the product's shelflife. Labels listing the type of noodle, nutritional facts, cooking instructions and expiration date are attached to the top of the containers. Dried pasta is loaded, either manually or mechanically, into stainless steel buckets which move along a conveyor belt to the appropriate packaging station. The pasta is measured by machine into pre-printed boxes, which also list the type of noodle, ingredients, preparation and expiration date.

To assess the quality of pasta, the semolina flour for color, texture and purity are tested before it is removed from rail cars (Lidon and Silvestre, 2007). Protein and moisture content are also measured. The technicians constantly further test the pasta for elasticity, texture, taste and tolerance to overcooking. Plant workers are required to wear helmets and plastic gloves. Mixing machines must also be scrupulously cleaned after each batch of pasta passes through them. The drying process is strictly monitored to guard against spoilage.

\subsection{Food additives requirements}

Fresh pasta foodstuffs are appreciated by consumers for its organoleptic characteristics, nutritive value, preservation, simplicity and security in use. In order to obtain quality fresh pasta products with the requirements of the consumers, namely a good appearance, tasty, that could be preserved for a longer period of time as possible, food additives are often used. However, only a few additives are allowed to be used in fresh pasta and no additives can be added to dry pasta. Fresh pasta requires food additives (Table 3) that can act as acidifiers (substances that increase the acidity of a food product and/or give it a sour taste), acidity regulators (substances that modify or control the acidity or alkalinity of a foodstuff), antioxidants (substances that prolong the shelf-life of food products, protecting them from deterioration caused by oxidation, like rancidity of fats and colour changes), emulsifiers (substances that make it possible to produce or maintain a homogeneous mixture of two or more immiscible phases, such as oil and water, in a food product), preservatives (substances that prolong the shelf-life of food products, protecting them from deterioration caused by microorganisms), sequestrants (substances which form chemical complexes with metallic ion), flavouring agents (additives that give food a particular taste or smell, and may be derived from natural ingredients or created artificially) and colours (substances which add or restore colour in foodstuffs).

All these food additives can be used in quantum satis, which mean that no maximum level is specified. However, additives must be used according with good manufacturing practice, at a level not higher than the necessary to achieve the intended purpose and provided that they do not misled the consumers (Directive, 1995). Although a large number of food additives used in food industry can have side effects for the consumer, the additives allowed in fresh pasta are considered nonhazardous. In this context, the food additive E270 Lactic acid, known by the chemical names of 2hydroxypropionic acid and 1-hydroxyethane-1carboxilic acid, is colourless or yellowish, nearly odourless, syrupy liquid with an acid taste, being often used with the technological functions of acid, acidifier, and preservative and obtained by lactic fermentation of sugars (but can also be prepared synthetically) (Directive, 1996). Ascorbic acid (E300), white or almost white, odourless crystalline solid which darkens on exposure to light, freely soluble in water, sparingly soluble in ethanol and insoluble in ether, also with the chemical names of L-ascorbic acid 2,3-Didehydro-L-threo-hexono-1,4lactone and 3-Keto-L-gulofuranolactone, is the most important natural antioxidant used as antioxidant in fresh pasta, protecting against deterioration caused by oxidation and extending the shelf-life of food. Sodium ascorbate (E301), white to slightly pale greyish-yellow odourless crystalline powder, freely soluble in water and very slight soluble in ethanol, with the chemical names of sodium ascorbate, sodium L-ascorbate, 2,3Didehydro-L-threo-hexono-1,4-lactone sodium enolate and 3-keto-L-gulofurano-lactone sodium enolate, is also an important antioxidant used in 
fresh pasta. Lecithin (phosphatides or phospholipids) is a natural food additive (E322) that can act as emulsifier and antioxidant in fresh pasta, making possible the formation and maintenance of homogeneous mixtures between two or more immiscible phases (namely oil and water), and can also extend the shelf-life by preventing oxidation. Lecithins are mixtures or fractions of phosphatides obtained by physical procedures from animal or vegetable foodstuffs; they also include hydrolysed products obtained through the use of harmless and appropriate enzymes (the final product must not show any signs of residual enzyme activity). The appearance of this food additive ranges from the brown liquid or viscous semi-liquid or powder depending on the source and whether it is bleached or unbleached and the hydrolysed lecithins are light brown to brown viscous liquid or paste. Citric acid (2hydroxy-1,2,3-propanetricarboxylic acid, $\beta$ hydroxytricarballytic acid), a white or colourless, odourless, crystalline solid, having a strongly acid taste very soluble in water, freely soluble in ethanol and slightly soluble in ether, is a food additive (E330) naturally present in citric fruits, which is used as acidulant, sequestrant, synergist for antioxidants, and flavouring agent of fresh pasta. This additive extends the shelf-life, acting against oxidation processes, and has no side effects to the consumer. L(+)-Tartaric acid (L-tartaric acid, L2,3- dihydroxybutanedioic acid, d- $\alpha, \beta-$ dihydroxysuccinic acid), a colourless or translucent crystalline solid or white crystalline powder, is an acidifier (E334) used to reduce the $\mathrm{pH}$ of fresh pasta, acting as obstacle against the microbial development (Nanu-Pacuar and Danciu, I., 2008). This additive can act also as synergic for antioxidants, sequestrant, and flavouring agent (FAO, 2011). Mono- and diglycerides of fatty acids (glyceryl monostearate, glyceryl monopalmitate, glyceryl monooleate, etc., monostearin, monopalmitin, monoolein, etc. or GMS (for glyceryl monostearate)) is an emulsifier (E471) used in fresh pasta (FAO, 2011) that can be from natural origin or can be synthesized from glycerin and fatty acid oils and fats. This additive is a mixture of mono- and diglyceryl esters of long chain saturated and unsaturated fatty acids that occur in food fats which contains at least $30 \%$ of alpha-monoglycerids and may also contain other isomeric monoglycerides, and di- and triglycerids, free glycerol, and free fatty acids. The product, that is insoluble in water, and soluble in ethanol, chloroform and benzene, varies from a pale yellow to pale brown oily liquid to a white or slightly offwhite hard waxy solid, and the solids may be in the form of flakes, powders or small beads. Gluconodelta-lactone (Gluconolactone, GDL, D-gluconic acid delta-lactone, delta-gluconolactone) is the cyclic 1,5-intramolecular ester of D-gluconic acid, and can be used as food additive (E575) with the functions of acidifier, razing agent and sequestrant in fresh pasta. This natural substance can be obtained by oxidation of glucose and doesn't have secondary effects known. This additive is a fine, white, nearly odourless, crystalline powder freely soluble in water, and sparingly soluble in ethanol (Directive, 2000). Fresh pasta products can also contain some natural colours and flavoring agents, or can be manufactured with ingredients that give cretin colors and flavors but are not considered food additives, such as eggs, spinach, tomatoes, etc.

Table 3. Food additives used in fresh pasta that are allowed by the European Union law.

\begin{tabular}{|c|c|c|}
\hline $\mathrm{E} \mathrm{N}^{\mathrm{o}}$ & Chemical name & Chemical formula \\
\hline E270 & Lactic acid & $\mathrm{C}_{3} \mathrm{H}_{6} \mathrm{O}_{3}$ \\
\hline E300 & Ascorbic acid & $\mathrm{C}_{6} \mathrm{H}_{8} \mathrm{O}_{6}$ \\
\hline E301 & Sodium ascorbate & $\mathrm{C}_{6} \mathrm{H}_{7} \mathrm{O}_{6} \mathrm{Na}$ \\
\hline E322 & Lecithins & A chemical mixture \\
\hline E330 & Citric acid & $\begin{array}{l}\text { (a) } \mathrm{C}_{6} \mathrm{H}_{8} \mathrm{O}_{7} \\
\text { (anhydrous) } \\
\text { (b) } \mathrm{C}_{6} \mathrm{H}_{8} \mathrm{O}_{7} \cdot \mathrm{H}_{2} \mathrm{O} \\
\text { (monohydrate) }\end{array}$ \\
\hline E334 & $\mathrm{L}(+)$-Tartaric acid & $\mathrm{C}_{4} \mathrm{H}_{6} \mathrm{O}_{6}$ \\
\hline E471 & $\begin{array}{l}\text { Mono- and } \\
\text { diglycerides of fatty } \\
\text { acids }\end{array}$ & (mixture) \\
\hline E575 & Glucono-delta-lactone & $\mathrm{C}_{6} \mathrm{H}_{10} \mathrm{O}_{6}$ \\
\hline
\end{tabular}

\section{Conclusion}

Through the years, the breeding programmes over the world have been able to provide germplasm with high-yielding, managementresponsive and input-efficient. The ultimate goal is to simultaneously increase yield and improve enduse grain quality of durum wheat in developing countries. Although environmental factors, such as maximum temperatures and water available during grain filling period, have important effects on wheat grain protein accumulation and quality for pasta technology, durum wheat quality is a genotype-dependent trait. In general, moderately high temperature, proper soil moisture (resulting from rainfall and irrigation) and adequate solar radiation may improve durum wheat quality. Some ecological factors, including soil physiological and chemical properties and geographic latitude, can also affect durum wheat quality. Nevertheless, 
wheat infections caused by phytopathogenic fungal strains can also have relevant implications, through mycotoxins production, at economical and on human health as well. Indeed, mycotoxins can be regarded as an adaptation to imposed abiotic and other stress factors by several fungus strains. Following a general perspective, the production of pasta requires high quality requires high quality raw material, yet although all food additives can be used in quantum satis, following good manufacturing practice, their levels must not be higher than the necessary to achieve the intended purpose.

\section{References}

Araus, J. L., T. Amaro, J. Casadesús, A. Asbati and M. M. Nachit. 1998. Relationships between ash content, carbon isotope discrimination and yield in durum wheat. Australian J. Plant Physiol. 25:835-842.

Ayalew, A., H. Fehrmann, J. Lepschy, R. Beck and D. Abate. 2006. Natural occurrence of mycotoxins in staple cereals from Ethiopia. Mycopathol. 162(1):57-63.

Bennet, S. J., N. Saidi and D. Enneking. 1998. Modelling climatic similarities in Mediterranean areas: a potential tool for plant genetic resources and breeding programs. Agric. Ecos. Env. 70:29-143.

Brown, N. A., M. Urban, A. M. Van de Meene and K. E. Hammond-Kosack. 2010. The infection biology of Fusarium graminearum: defining the pathways of spikelet to spikelet colonisation in wheat ears. Fungal Biol. 114(7):555-571.

Blumenthal, C. S., I. L. Batey, F. Bekes, C. W. Wrigley and E. W. R. Barlow. 1991. Seasonal changes in wheat-grain quality associated with high temperatures during grain filling. Australian J. Agric. Res. 42(1):21-30.

Campbell, C. A., H. R. Davidson and G. E. Winkelman. 1981. Effect of nitrogen, temperature, growth stage and duration of moisture stress on yield components and protein content of Manitou spring wheat. Canadian J. Plant Sci. 61:549-563.

CEC. 2006. Commission Regulation (EC) $\mathrm{N}^{\circ}$ 1881/2006 of 19 December setting maximum levels for certain contaminants in foodstuffs. OJEU L-364:5-24.

Cossani, C. M., G. A. Y. Slafer and R. Savin. 2009. Yield and biomass in wheat and barley under a range of conditions in a Mediterranean site. Field Crop Res. 112:205-213.

Czerwiecki, L., D. Czajkowska and A. WitkowskaGwiazdowska. 2002. On ochratoxin A and fungal flora in Polish cereals from conventional and ecological farms. Part 2: occurrence of ochratoxin A and fungi in cereals in 1998. Food Addit. Contam. 19(11):1051-7.

Dias, S., J. Semedo, J. C. Ramalho and F. C. Lidon 2011. Bread and durum wheat under heat stress: a comparative study on the photosynthetic performance. J. Agron. Crop Sci. 197:50-56.

Dias, A. S., M. G. Barreiro, P. S. Campos, J. C. Ramalho and F. C. Lidon. 2010. Wheat cellular membrane thermotolerance under heat stress. J. Agron. Crop Sci. 196:100-108.

D'Mello, J. 2004. Contaminants and toxins in animal feeds. FAO Animal Production Health Papers 160:107-129.

Directive 95/2/EC of the European Parliament and of the Council of the $20^{\text {th }}$ February. 1995.

Directive 96/77/EC of the European Parliament and of the Council of the $2^{\text {nd }}$ of December. 1996.

Directive 2000/63/EC of the European Parliament and of the Council of the $5^{\text {th }}$ of October. 2000.

Duarte, S. C., J. Bento, A. Pena, C. M. Lino, C. Delerue-Matos, M. B. Oliveira, M. R. Alves and J. A. Pereira. 2010. Influencing factors on bread-derived exposure to ochratoxin A: type, origin and composition. Food Chem. Toxicol. 48(8-9):2139-2147.

FAO. 2011. http://www.fao.org/ag/agn/jecfaadditives/search.html

Ghali, R., K. Hmaissiakhlifa, H. Ghorbel, K. Maaroufi and A. Hedili. 2008. Incidence of aflatoxins, ochratoxin $\mathrm{A}$ and zearalenone in Tunisian foods. Food Control 19:921-924.

Giese, J. 1992. Pasta: New Twists on an Old Product. Food Technol. 118:121-126.

Gonzalez, F. and C. Rojo. 2005. Gramíneas y seudocereales. En Prontuario de Agricultura. Co-Edición Ministerio de Agricultura Pesca y Alimentación y Ediciones Mundi-Prensa. Madrid, pp. 3-228.

Gonzalez-Osnaya, L., J. M. Soriano, J. C. Molto and J. Manes. 2007. Dietary intake of ochratoxin A from conventional and organic 
bread. Internat. J. Food Microbiol. 118(1):8791.

Graybosch, R. A., C. J. Peterson, P. S. Baenziger and D. R. Shelton. 1995. Environmental modification of hard red winter wheat flour protein composition. J. Cereal Sci. 22(1):4551.

Hope, R. and N. Magan. 2003. Two-dimensional environmental profiles of growth, deoxynivalenol and nivalenol production by Fusarium culmorum on a wheat-based substrate. Lett. App. Microbiol. 37(1):70-74.

IARC. 1993. International Agency for Research on Cancer: Monographs on the Evaluation of Carcinogenic Risks to Humans. IARC 56:257263.

Jayashree, T. and C. Subramanyam. 2000. Oxidative stress as a prerequisite for aflatoxin production by Aspergillus parasiticus. Free Rad. Biol. Med. 29(10):981-985.

JECFA. 2001. Safety evaluation of certain mycotoxins in food. WHO Food Additives Series, p. 47.

Kellogg, A., R. Appels and J. Mason-Gamer. 1996. When genes tell different stories: The diploid genera of the Triticeae (Gramineae). Syst. Bot. 21:321-347.

Lev-Yadun, S., A. Gopher and S. Abbo. 2000. The cradle of agriculture. Sci. 288:1602-1603.

Lidon, F. C. and M. M. A. S. Silvestre. 2007. Industrias alimentares-aditivos e tecnologias. Escolar Editora, ISBN:9789725922033.

López Bellido, L. 1991. Cultivos herbáceos Vol. I. Ediciones Mundi-Prensa. Madrid: 26-236.

López Bellido, L. 2009. Informe sobre: Cuestiones referentes al sector de herbáceos, más relevantes para la definición de la Politica de Seguros Agrarios: Situación actual y tendencias a corto plazo. Desarrollos Agrotecnológicos Integrados. S.L. Empresa de Base tecnológica de la Universidad de Córdoba, Universidad de Córdoba.

Loss, S. P. and K. H. M. Siddique, 1994. Morphological and physiological traits associated with wheat yield increases in Mediterranean environments. Adv. Agron. 52:229-276.
Maçãs, B. M. 1996. Definição de critérios de selecção de trigo mole (Triticum aestivum L.) para as condições do ambiente mediterrânico do Sul de Portugal. Elvas. p. 90.

Maçãs, B. M., M. C. Gomes and A. S. Dias. 1999. Efeito das temperaturas elevadas durante o enchimento do grão em trigo mole e rijo no Sul de Portugal. Melhoramento 36:27-45.

Maçãs, B. M., M. C. Gomes, A. S. Dias and J. N. P. Coutinho. 2000. The tolerance of durum wheat to high temperatures during grain filling, In: C. Royo, M. M. Nachit, N. Di Fonzo and J. L. Araus (Eds.), pp. 257-261. Options Méditerranéennes - Durum wheat improvement in the Mediterranean region: new challenges, Serie A40, CIHEAM, Zaragoza, Espanha.

Manzano, J. R. 2007. Prolaminas y marcadores moleculares relacionadas con la calidad en Trigo Duro (Triticum turgidum L.). Tesis Doctoral. Escuela Técnica Superior de Ingenieros Agrónomos. Universidad Politécnica de Madrid. Madrid.

Miraglia, M., H. J. Marvin, G. A. Kleter, P. Battilani, C. Brera, E. Coni, F. Cubadda, L. Croci, B. De Santis, S. Dekkers, L. Filippi, R. W. Hutjes, M. Y. Noordam, M. Pisante, G. Piva, A. Prandini, L. Toti, G. J. van den Born and A. Vespermann. 2009. Climate change and food safety: an emerging issue with special focus on Europe. Food Chem. Toxicol. 47(5):1009-1021.

Morancho, J. 2000. Production et commercialization du blé dur dans le monde, In: N. Di Fonzo, F. Kaan, M. Nachit (Eds.), Durum Wheat Improvement in Mediterranean Region", New Challenges, CIHEAM, Zaragoza. Options Méditerranéennes A.40:1934.

Muller, M., A. Brenning, G. Verch, S.Koszinski and M. Sommer. 2010. Multifactorial spatial analysis of mycotoxin contamination of winter wheat at the field and landscape scale. Agric. Ecos. Env. 139:245-254.

Muthomi, J. W., J. Ndungú, J. Gathumbi, E. Mutitu and J. M. Wagacha. 2008. The occurence of Fusarium species and mycotoxins in Kenyan wheat. Crop Prot. 27:1215-1219.

Nachit, M. M., M. E. Sorells, R. W. Zobel, H. G. Gauch, R. A. Fisher and W. R. Coffman. 
1992. Association of morpho-physiological traits with grain yield and components of genotype-environment interaction in durum wheat I and II. J. Gen. Breed 46:363-368.

Narasaiah, K. V., R. B. Sashidhar, C. Subramanyam. 2006. Biochemical analysis of oxidative stress in the production of aflatoxin and its precursor intermediates. Mycopathol. 162(3):179-189.

Nanu-Pacuar and I. Danciu. 2008. Additives used in flour pasta fabrication. J. Agroal. Process. Technol. 14:306-308.

Nuñez, V. M. M. 2003. Influencia del régimen hídrico sobre parámetros de la calidad del trigo duro (Triticum durum Desf.) en ambiente mediterraneo. Granada University, Spain.

Palermo, D., P. Pietrobono, C. Palermo and T. Rotunno. 2002. Occurence of ochratoxin A in cereals from Puglia (Italy). Italian J. Food Sci. 14:447-453.

Prandini, A., S. Sigolo, L. Filippi, P. Battilani and G. Piva. 2009. Review of predictive models for Fusarium head blight and related mycotoxin contamination in wheat. Food Chem. Toxicol. 47(5):927-931.

Palumbo, M., A. Spina and G. Boggini. 2000. Agronomic and bread-making characteristics of durum wheat genotypes deriving from interspecific hybridization with bread wheat, In: C. Royo, M. M. Nachit, N. Di Fonzo, J. L. Araus (Eds.), Durum wheat improvement in the Mediterranean region, new challenge. CIHEAM, Zaragoza. Options Mediterraneennes A. 40:515-518.

Quaglia, G. B. 1988. Other durum wheat products, In: G. Fabriana, C. Lintas (Eds.). pp. 263-282. Durum wheat: chemistry and technology, AACC International. St. Paul, Minnesota. USA.

Qutet, S., A. Shehata, A. Mesellam. 1983. Occurence of aflatoxins in some Egyptian food crops collected from two coastal regions. Food Chem. 10:149-153.

Rao, A. C. S., J. L. Smith, V. K. Jandhyala, R. I. Papendick and J. F. Pan. 1993. Cultivar and climatic effects on the protein content of soft White Winter wheat. Agron. J. 85:1023-1028.

Reverberi, M., A. Ricelli, S. Zjalic, A. A. Fabbri and C. Fanelli. 2010. Natural functions of mycotoxins and control of their biosynthesis in fungi. App. Microbiol. Biotechnol. 87(3):899-911.

Rharrabti, Y., D. Villegas, L. F. Garcia del Moral, N. Aparicio, S. Ehani, C. Royo. 2001. Environmental and genetic determination of protein content and grain yield durum wheat under mediterranean conditions. Plant Breed. 20:381-388.

Rharrabti, Y., D. Villegas, C. Royo, V. MartosNúñez and F. García del Moral. 2003. Durum wheat quality in Mediterranean environments: II. Influence of climatic variables and relationships between quality parameters. Field Crop. Res. 80:133-140.

Robinson, F. E., D.W. Cudney and W. F. Lehman. 1979. Nitrogen fertilizer timing, irrigation, protein and yellow berry in durum wheat. Agron. J. 71: 304-308.

Roncallo, P., I. Garbus, A. Picca, V. Echenique, D. A. Carrera, G. L. Cervigni and R. Miranda. 2009. Análisis de las bases genéticas del color en trigo candeal. Revista de la Facultad de Agronomia/La Plata. Buenos Aires 108(1):923.

Royo, C. 1998. Limitaciones ambientales al cultivo del trigo duro. Vida Rural 5(70): 26-28.

Schmidt-Heydt, M., A. Abdel-Hadi, N. Magan and R. Geisen. 2009. Complex regulation of the aflatoxin biosynthesis gene cluster of Aspergillus flavus in relation to various combinations of water activity and temperature. Internat. J. Food Microbiol. 135(3):231-237.

Schmidt-Heydt, M., E. Baxter, R. Geisen and N. Magan. 2007. Physiological relationship between food preservatives, environmental factors, ochratoxin and otapksPV gene expression by Penicillium verrucosum. Internat. J. Food Microbiol. 119(3):277-283.

Schmidt-Heydt, M., N. Magan and R. Geisen. 2008. Stress induction of mycotoxin biosynthesis genes by abiotic factors. FEMS Microbiol. Lett. 284(2):142-149.

Schmidt-Heydt, M., C. Rufer, F. Raupp, A. Bruchmann, G. Perrone and R. Geisen. 2011. Influence of light on food relevant fungi with emphasis on ochratoxin producing species. Internat. J. Food Microbiol. 145(1):229-237.

Scudamore, K. A., S. Patel and V. Breeze. 1999. Surveillance of stored grain from the 1997 
harvest in the United Kingdom for ochratoxin A. Food Addit. Contam. 16(7):281-290.

Slafer, G. A. 2003. Genetic basis of yield as viewed from a crop physiologist's perspective. Ann. App. Biol. 142:117-128.

Toussaint-Samat, M. 1992. A History of Food. Blackwell Publishers, UK.

EU. 2010. Regulation (UE) $\mathrm{N}^{\mathrm{o}} 165 / 2010,26^{\text {th }}$ February 2010, Fixa os teores máximos de certos contaminantes presentes nos géneros alimentícios, no que diz respeito às aflatoxinas. JOUE L-50:8-12.

Uhlen, A. K., R. Hafskjold, A. H. Kalhovd, S. Sahlström, Å. Longva and E. M. Magnus. 1998. Effects of cultivar and temperature during grain filling on wheat protein content, composition, and dough mixing properties. Cereal Chem. 75(4):460-465.
Whitlow, L. W. and W. M. Hagler. 2005. Mycotoxins in feeds. Feedstuffs 14:69-79.

Yoshizawa, T. 1997. Geographic difference in trichothecene occurence in Japanese wheat and barley. Bull. Institut. Compr. Agric. Sci. Kinki Univ. 5:23-30.

Zaied, C., S. Abid, L. Zorgui, C. Bouaziz, S. Chouchane, M. Jomaa and H. Bacha. 2009. Natural occurence of ochratoxin A in Tunisian cereals. Food Control 20:218-222.

Zinedine, A., C. Brera, S. Elaskhdari, C. Catano, F. Debegnach, S. Angelini, B. De Santis, M. Faid, M. Benlemlih, V. Minardi and M. Miraglia. 2006. Natural occurrence of mycotoxins in cereals and spices commercialized in Morocco. Food Control 17:868-874. 